\title{
Abrasax: A Magical Gem in the Istanbul Archaeological Museums
}

Sencan Altınoluk and Nilüfer Atakan

\section{Q OpenEdition \\ 1 Journals}

Electronic version

URL: http://journals.openedition.org/anatoliaantiqua/303

DOI: 10.4000/anatoliaantiqua.303

\section{Publisher}

IFEA

\section{Printed version}

Date of publication: 1 January 2014

Number of pages: $219-223$

ISBN: 9782362450136

ISSN: 1018-1946

\section{Electronic reference}

Sencan Altınoluk and Nilüfer Atakan, «Abrasax: A Magical Gem in the Istanbul Archaeological Museums », Anatolia Antiqua [Online], XXII | 2014, Online since 30 June 2018, connection on 18 December 2020. URL : http://journals.openedition.org/anatoliaantiqua/303 ; DOI : https://doi.org/ 10.4000/anatoliaantiqua.303 


\section{ANATOLIA ANTIQUA ESKI ANADOLU}

\section{XXII}

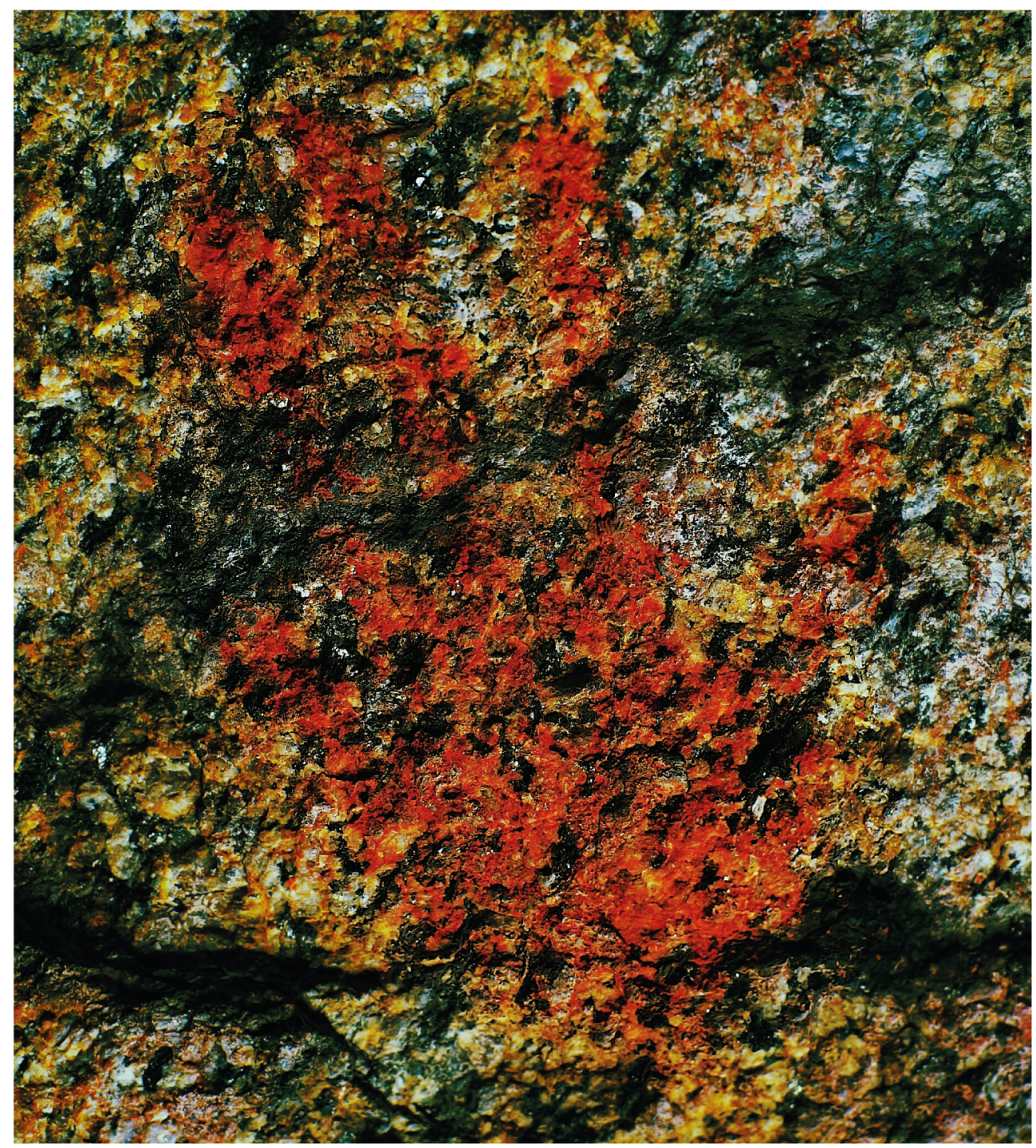

INSTITUT FRANÇAIS D'ETUDES ANATOLIENNES GEORGES-DUMEZIL CNRS USR 3131

DE BOCCARD 


\section{TABLE DES MATIERES}

Emma BAYSAL,

A preliminary typology for beads from the Neolithic and Chalcolithic levels of Barcın Höyük

William ANDERSON, Jessie BIRKETT-REES, Michelle NEGUS CLEARY,

Damjan KRSMANOVIC et Nikoloz TSKVITINIDZE,

Archaeological survey in the South Caucasus (Samtskhe-Javakheti, Georgia):

Approaches, methods and first results

Eda GÜNGÖR ALPER,

Hellenistic and Roman period ceramic finds from the Balatlar Church excavations in

Sinop between 2010-2012

Ergün LAFLI et Gülseren KAN ŞAHİN,

Hellenistic ceramics from Southwestern Paphlagonia

Oğuz TEKIN,

Weights of Lysimachea from the Tekirdağ Museum and various collections

Oğuz TEKIN,

Three weights of Lampsacus

Julie DALAISON et Fabrice DELRIEUX,

La cité de Néapolis-Néoclaudiopolis : histoire et pratiques monétaires

Martine ASSENAT et Antoine PEREZ,

Amida 4. Constance II et Amida

Sencan ALTINOLUK et Nilüfer ATAKAN,

Abrasax: A magical gem in the Istanbul Archaeological Museums

Bahadır DUMAN,

A group of local production Middle Byzantine period pottery from Tripolis:

'Micaceous White Painted Ware'

CHRONIQUES DES TRAVAUX ARCHEOLOGIQUES EN TURQUIE, 2014

Jean-Charles MORETTI,

avec la collaboration de Nicolas BRESCH, Isabel BONORA, Jean-Jacques MALMARY et

Olivier RISS,

Claros, le Temple d'Apollon : travaux réalisés en 2013

Suat ATEŞLIER,

On the excavations of the Zeus Temple of Alabanda 
Olivier HENRY,

avec Ayşe Güliz BİLGIN ALTINÖZ, Jesper BLID, Ömür Dünya ÇAKMAKLI, Andrew DUFTON, Agneta FRECCERO, Linda GOSNER, Ragnar HEDLUND, Pascal LEBOUTEILLER,

Vasilica LUNGU, Felipe ROJAS, Fredrik TOBIN, Baptiste VERGNAUD et

Andrew WATERS,

La mission Labraunda 2013 - Rapport préliminaire

Dominique BEYER, Isabelle CHALIER, Françoise KIRNER,

Françoise LAROCHE-TRAUNECKER et Aksel TIBBET,

Zeyve Höyük - Porsuk. Rapport préliminaire sur la campagne 2013

Çiğdem MANER,

Preliminary report on the first season of the Konya-Ereğli (KEYAR) survey 2013 


\section{ABRASAX \\ A MAGICAL GEM IN THE ISTANBUL ARCHAEOLOGICAL MUSEUMS}

\section{FIND PLACE AND PRESERVATION}

The following gem (Fig. 1) - a red jasper with black ribbons, measuring $17 \times 13 \times 3 \mathrm{~mm}$ and weighing $1.26 \mathrm{~g}-$ is preserved in the Istanbul Archaeological Museums ${ }^{1}$. It was found during a rescue excavation in the Province of Istanbul, district of Eminönü, in the quarter of Cankurtaran, in Akbiyık Hamamı Street (map sheet 60, parcel 57)2. The gem was apparently trimmed in antiquity, so that the anguipede god's legs may be missing ${ }^{3}$, as well as some letters of the inscriptions; otherwise the gem is well preserved, all its details are clearly identifiable. The stonecutter tried to avoid round forms of letters which were quite difficult to engrave. Therefore the omikron and theta are composed of four diagonal strokes, alpha is written as a minuscule letter with three strokes; the curve of rho is formed by two diagonal strokes.

\section{THE REPRESENTATION OF ABRASAX}

The gem shows the god Abrasax (or Abraxas) in his usual iconography ${ }^{4}$ as an armoured anguipede giant with the head of a rooster, a whip in his right hand and an oval shield in his left. The shield is decorated with a magical sequence of letters, of which some are identifiable with the names of gods and demons, some are cryptic.

Abrasax is the god of the solar year and the letters of his name have the isopsephic value of 365 $(\mathrm{A}=1, \mathrm{~B}=2, \mathrm{P}=100, \mathrm{~A}=1, \Xi=60, \mathrm{~A}=1, \mathrm{C}=$ $200)^{5}$. Abrasax was thought to be a mighty tutelary deity. People imagined him as a kind of sun god similar to the Greek Helios, who could protect people all of the year - i.e. 365 days - and who was able to see everything that happens on earth ${ }^{6}$. A. Barb explains the appearance of Abrasax - an anguipede giant with rooster head - by the fact that

*) Sencan Altınoluk, Çanakkale Onsekiz Mart University, Department of Archaeology, 17100 Çanakkale. E-mail: zsencan@hotmail.com

**) Nilüfer Atakan, retired archaeologist from Istanbul Archaeological Museums. E-mail: nilatakan@gmail.com

1) Istanbul Archaeological Museums, Department of Metal Objects, inv. $\mathrm{n}^{\circ} 02.8 \mathrm{M}$

2) We are very grateful to the director of the Istanbul Archaeological Museums, Zeynep Kiziltan, who gave permission for its publication, as well as Gülbahar Baran Çelik, archaeologist and vice director of the museum, and Mine Kiraz, archaeologist, for their strong support and advice during our studies in the museum, and Sefer Arapoğlu who was the head of the excavations at Eminönü when the gem was found.

3) The god's anguipede legs are sometimes not represented, cf. e.g. Gonzalez and Prieto 1993: 130: "Die Mittelfigur hat einen Hahnenkopf mit seitwärts gerichtetem Schnabel; sie hält einen halbmondförmigen Schild in ihrer Rechten; in der Linken hat sie eine Peitsche, deren Geißel fehlt. Es sind keine Beine zu sehen, weder menschliche noch schlangenförmige, was vermuten läßt, daß der untere Teil der Figur Federn darstellt und nicht ein kurzes Röckchen. Im unteren linken Teil der Platte gibt es sieben Sterne, die die sieben Planeten darstellen und wie ein Mond im letzten Viertel angeordnet sind".

4) Cf. Zazoff 1965: 102: "Über den Gott Abraxas ist viel geschrieben worden. Der mit Gigantenbeinen versehene, also mit Schlangen endende Körper ist muskulös, meistens bedeckt ihn der Panzer eines römischen Legionärs, wie auch der Schild zur Soldatenausrüstung gehört: die irdische Macht nach Vorstellung der römischen Spätantike. Der Hahnenkopf dürfte einerseits durch den Bezug des Tieres zum Licht und zum Helios, andererseits durch ein Wortspiel zum Bestandteil des Abraxas geworden sein. Die Geißel ist einmal Attribut des Lichtgottes, zum andern ein Symbol zum Abwehren des Bösen. Die Bedeutung der schlangenbeinigen, hahnenköpfigen Gestalt und ihre Verbreitung innerhalb der magischen Glyptik war so groß, daß den Gemmen seit dem 17. Jh. der Name Abraxas-Gemmen gegeben wurde.”; Philonenko 1979 and especially Le Glay 1981.

5) E.g. Merkelbach and Totti 1990: IX.

6) For this ability of Helios $c f$. Nollé 2007: 252. 
the Hebrew root GBR may be vocalized GiBoR, which means 'warrior, good soldier' as well as GeBeR, what is the Hebrew word for 'rooster'. GiBoR was used as the Hebrew synonym for the Greek $\gamma$ í $\gamma \alpha \varsigma /$ giant $^{7}$. In Greek and Roman belief the rooster was generally considered to be a protector from evil ${ }^{8}$, as the rooster guards the farm where it lives, and as the Greek name of the animal was connected with the verb $\alpha \lambda \dot{\varepsilon} \xi o \mu \alpha 1$, 'to ward off, to avert'. Furthermore, this animal was very often associated with the sun ${ }^{9}$, as roosters are wont to crow at sunrise, which was interpreted as a kind of greeting to the rising sun. Roosters are widely used in magic practices and rituals ${ }^{10}$. The whip and the shield are thought to be used for warding off demons. Therefore such gems are applied for the purposes of protecting their wearers from any sort of evil. Also the whip assimilates Abrasax to the sun god who uses his whip to drive his horses on. In the case of Abrasax the whip is a symbol of the god's power to prevent demons from attacking the owner of such a gem. Abrasax's shield is an instrument to protect men from demons and all kinds of evil. The idea that a god shields men may be traced backed to the Jewish Old Testament (Genesis XV 1), where the mighty god is called 'Abrahams shield'"1. For this reason it is not very surprising that the name of the Jewish god Iahwe is frequently written on Abrasax's shield.

Also on this gem Abrasax is clad in Roman military uniform. Martin Persson Nilsson has very precisely discussed the background and meaning of this costume which expresses Abrasax' power:

"In the age under discussion foreign gods, Egyptian, Syrian, etc., appear frequently in Roman military costume. So, for example, a bronze statuette represents Sarapis in the costume of the Imperator with the globe in his left hand, a spear in his right; on his head are traces of the disc of the sun. He is the god who rules the world. The best known example is the Syrian god Jupiter Dolichenus. The soldiers were wont to pay cult to gods in military costume, their emperors, and the people of the provinces worshipped the emperors for they knew that the overwhelming power of the Romans depended on their weapons, and so they clad their gods in the Roman military costume to express their power" ${ }^{\prime 2}$.

Besides the depiction of Abrasax there are four stars. As the god is assimilated with the sun, the ruler of the cosmos, very often we find seven stars which represent the seven planets orbiting the sun. But sometimes there are only three or five of them ${ }^{13}$, so that we cannot be sure how many stars were originally depicted on this gem.

\section{THE INSCRIPTIONS}

On the obverse, in the left margin, in the first vertical line, it reads ['A $\beta] \rho \alpha \sigma[\alpha \dot{\xi} \xi]$

On the obverse, in the left margin, in the second vertical line, it reads ['A] $\rho \alpha \mu \mu \alpha \chi \alpha \mid \mu \alpha ́[\rho \varepsilon 1]$; ' $\mu \alpha$ ' is found over the head of the figure and it is placed upside down while the ' $\rho \varepsilon \imath$ ' is off gem. Many

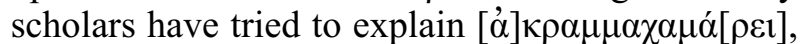
which is found in many magical papyri and on magical gems. Gershom G. Scholem, who discussed some older interpretations, thought that

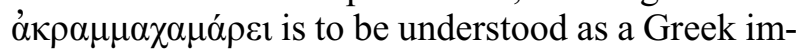
perative form that was composed of the Aramaic expressions for 'uproot, destroy' and 'net' ${ }^{14}$. In the magical sphere the special meaning of 'net' is 'evil

7) Barb 1957: 77

8) Orth 1913: 2531; Lacroix 1965: 122 f.: "De même que le serpent protège l'autel de l'Hypsas, le coq veille sur l'autel du Sélinous. A cause de son chant qui annonce de lever du jour, on prête, en effet, à cet animal le pouvoir de chasser les esprits malfaisants et d'écarter les mauvaises influences. Ce pouvoir aurait valu au coq le nom d'á $\lambda \dot{\varepsilon} \kappa \tau \omega \rho$ ou $\alpha \dot{\lambda} \varepsilon \kappa \tau \rho v ́ \omega v$, que l'on rattache au verbe $\grave{\alpha} \lambda \hat{\varepsilon} \xi \omega$, 'défendre'. Les vertus prophylactiques du coq sont du reste attestées de diverses manières. Ce volatile combat le mauvais œil, son image est utilisée comme amulette, elle figure en épisème sur les boucliers et elle apparaît sur les vases auprès des yeux apotropaïques. La puissance magique du coq a permis de l'associer au rituel funéraire et de lui confier la garde du tombeau : sur la stèle d'Antiphanès, un coq était peint à la partie supérieure, au-dessus du nom du défunt."; $c f$. Michel 2004: 106-110.

9) Orth 1913: 2531; Dölger 1920: 43; Fauth 1995: 143

10) Güntert 1930/1.

11) Barb 1957: 78: "Das Schild dieses Giganten trägt in der Mehrzahl der Darstellungen die Inschrift IAO, das will ausdrücken, dass dieses Schild = IAO: Man vergleiche dazu Genesis XV, 1, wo sich Gott selbst als 'Schild' Abrahams bezeichnet und die zahlreichen Stellen in den Psalmen, wo er als 'Schild' bezeichnet wird".

12) Nilsson 1951: 61.

13) Zazoff 1965, 103: "Die Darstellung unterscheidet sich von Nr. 55 durch das Fehlen der Beischriften, an deren Stelle die sieben Sterne im Raum verstreut sind. Sie deuten auf die sieben Planeten und auf Abraxas als 'den umfassenden, allmächtigen kosmischen Gott, Herrn der Sonne, des Lichtes und des Himmels, des Menschenlebens wie der Unterwelt', das gesamte Universum volkstümlichen Glaubens umfassend". In footnote 234 he mentions that there are sometimes only three or five stars; Gonzalez and Prieto $1993: 130$ (seven stars).

14) Scholem 1965: 97: “The whole formula constitutes an imperative - 'uproot the magic spells' which might be directed against the bearer of an amulet”. 

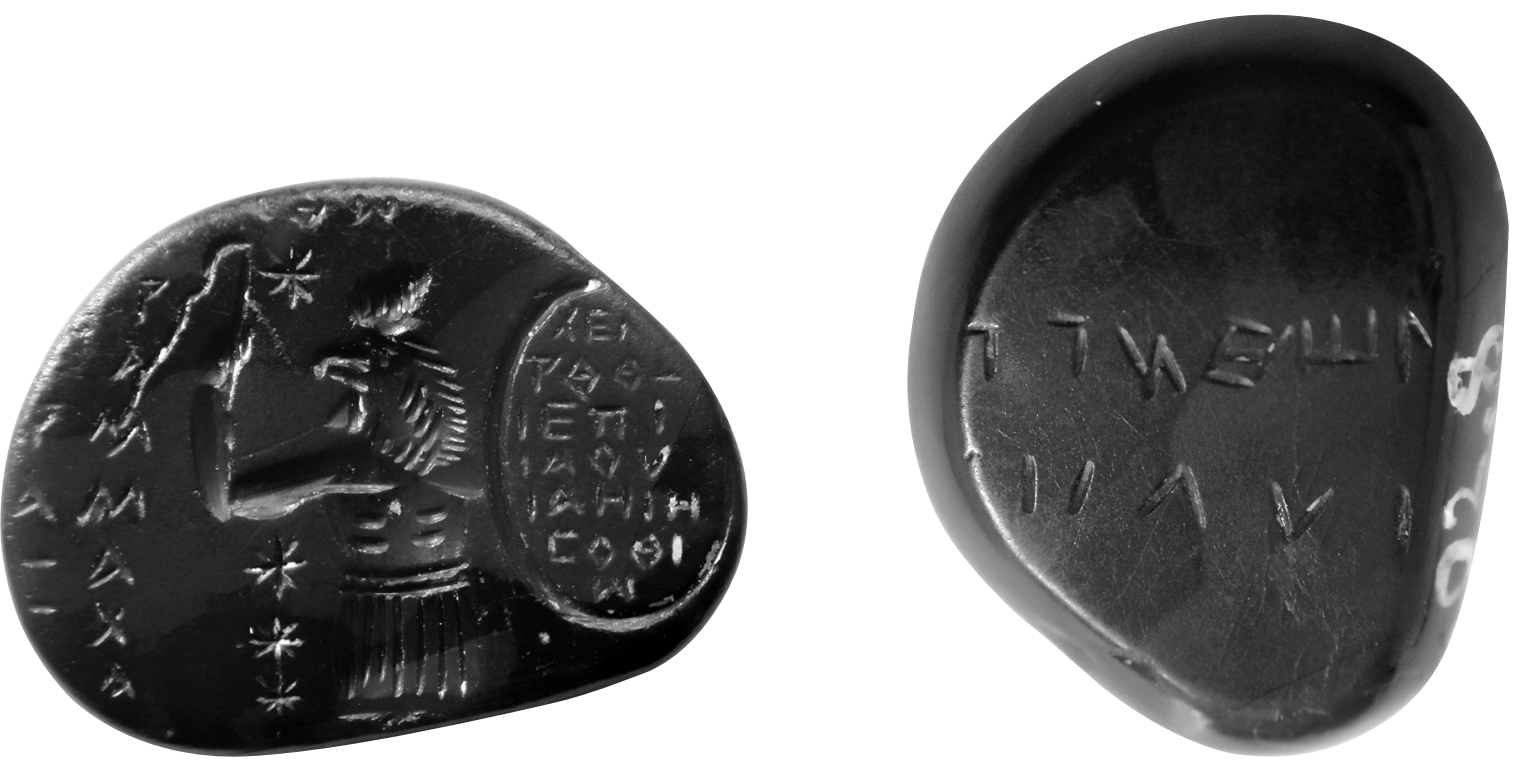

Fig. 1 : Gem, Istanbul Archaeological Museums, Department of Metal Objects, inv. $\mathbf{n}^{0} 02.8 \mathrm{M}$.

magic', by which a person could get caught. On a gem such an imperative should help to avert harm from the bearer of the amulet. This interpretation is quite problematical, as some magical papyri explicitly

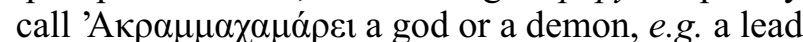
tablet from Carthage with a binding spell against the circus faction of the Reds. In 1. 7/8 we can read:

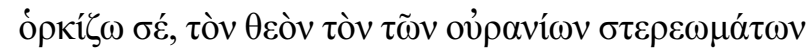

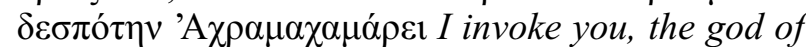
the celestial firmaments, you the Lord Achramachamare $^{15}$. And in a magical papyrus the sun god Helios in the shape of a tom cat - an animal sacred

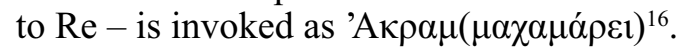

It is impossible to find out, what the owners of this magical gem exactly associated with the word, but it seems us quite possible that they took it as an epithet of Abrasax whose solar character is undisputed. The juxtaposition of ['A $\beta] \rho \alpha \sigma[\alpha \xi \xi]$ and ['A] $\rho \alpha \mu \mu \alpha \chi \alpha \mid \mu \alpha ́[\rho \varepsilon 1]$ gives some support to this view. In the right margin, on the oval shield, it reads:

$$
\begin{aligned}
& \chi \varepsilon .[. ?] \\
& \rho \theta \theta .[. ?] \\
& 1 \varepsilon \pi[[. ?] \\
& \text { Ioov [.?] }
\end{aligned}
$$

\author{
$1 \alpha \eta \imath$ \\ $\Sigma o \theta \mathrm{l}$ \\ $\omega$
}

We are not absolutely certain about the exact number of letters in the first four lines of the shield inscription. The same is the case for the meaning of most of these magical words. The first line reminds us to the Egyptian word 'chepri' in Greek transcription $(\chi \varepsilon \pi[\rho 1]$ ?), but this association has no certainty, as the third letter is not clearly legible. 'Chepri' is the Egyptian word for 'scarab' and also means 'to come into being, to come into existence' ${ }^{17}$. In 1.4 we may associate it with a form of I $\alpha \omega$, in 1.6 with Sothis. The name of the Jewish god Iahwe or its shorter form I $\alpha \omega$ is usually found on the protective shield of Abrasax, as Nilsson underlined in the discussion of Campbell Bonners fundamental book on magical gems:

"Professor Campbell Bonner does not attach great weight to the fact that the name Iao is often inscribed on the shield of the anguipede. He may be right, for the name of the Jewish god is used in the magic papyri chiefly as a magical word; only once is he said to be the creator of the world. But it is significant that the name is so constantly added to the anguipede" 18 .

15) Merkelbach 1996: 47-57, esp. $48 \mathrm{f}$. with a short comment on 55: “A $\chi \rho \alpha \mu(\mu) \alpha \chi \alpha \mu \alpha \rho$ ist ein häufiger Geheimname, der noch unerklärt ist”. Merkelbach refers to another magical papyrus, cited above.

16) Merkelbach and Totti 1991: $10 \mathrm{f}$.

17) Merkelbach 1992: 14: 'Das ägyptische Wort für den Skarabäus ist 'Chepri', und Chepri bedeutet gleichzeitig 'das Werden'. Es kommt in unserem Text in der lautlich etwas veränderten Form $\mathrm{Ch}(\mathrm{e})$ phuri vor. Chepri bezeichent also die ewige Erneuerung”.

18) Nilsson 1951: 64. 
There are a lot of mystic and magical speculations about the Jewish god and his cryptic name: The three vowels of his name were interpreted as the three columns of the world ${ }^{19}$, and there is also the widespread equation of Iahwe and Helios ${ }^{20}$. Therefore by the use IA $\Omega$ (or one of its different spellings) Abrasax is once again stylized as a cosmocratic sun god. The Egyptians called the Dog Star (Sirius) Sothis. Its annual rising was the beginning of the Egyptian year ${ }^{21}$, this means the birthday of Abrasax, the year's Lord. There are many different forms and spellings, e.g. $\Sigma \omega \theta \eta=\Sigma \omega \theta \mathrm{r}$ as here, $\Sigma \omega \theta \alpha \lambda i s$, $\Sigma \omega \theta \alpha \rho \alpha, \Sigma \omega \theta \varepsilon \omega \theta, \Sigma \omega \theta^{22}$. It could be that the other letters have a special meaning, but it might also be the case that some of them - e.g. $\rho \theta \theta[-$ are only written down to create a magical sphere: "It may be that mere charlatanism is at work, and the meaningless words are intended only to impress the ignorant and credulous" 23 .

The engraver of this gem has consciously chosen the last letter of the Greek alphabet as the last letter of his sequence of magical letters. On the reverse, while the first line reads 77 EIШN[ГГ] the second line reads II $\mathrm{VI}[\mathrm{I}]$. We think that both sequences of magical characters make use of similar structures, such as parallelism and the change of orientation: The first line started with two left oriented gammas, then a left oriented $n y$, then the magical word $\varepsilon 1 \omega$ (a iotacistic writing of $1 \omega$ ? $)^{24}$ then a right oriented $n y$, and probably two right oriented gammas which are no longer preserved. In the second line we meet with two pairs of vertical strokes or iotas, which frame a lambda shaped sign in normal position and another one which was turned upside down. The last sequence is used on another Abrasax gem in the British Museum ${ }^{25}$.

\section{THE GEM AND ITS DATING}

It is very difficult to date such gems exactly. Even the forms of their letters are not very helpful. Usually such objects date to the later $3^{\text {rd }}$ or $4^{\text {th }}$ century A.D. This is the period, when the traditional city cults lost the support of their followers, the cult of the sun god became very prominent, and, in view of the many difficulties which most people experienced, magic gained an immense popularity. It seems that it was precisely at this period that the Abrasax gems are the most widely spread magical amulets in Antiquity $^{26}$. They are a product of the syncretism of the $3^{\text {rd }}$ century A.D., mixing Persian, Egyptian, Jewish, Christian, as well as Greek and Roman religious and superstitious traditions together. This gem is apparently a further proof of this cultural development.

S.A. and N.T.

19) Harrauer 1992: 41: "IA $\Omega$ wird vom hebräischen Jahwe hergeleitet und tritt besonders im 2./3. Jh. n. Chr. (und darüber hinaus) mit Vorliebe mit Abrasax auf. IA $\Omega$ wird aber auch als eine Variante der Vokale gedeutet (in umgruppierter Abfolge sind das der erste, letzte und mittlere Vokal von A $\varepsilon \eta$ I o $v \Omega$, also die 'Säulen des Alphabets, der Welt'). Der isopsephische 'Umrechnungswert' von Abrasax (oder Abraxas) mit 365 ) das Jahr, das Weltenjahr ist hinlänglich besprochen".

20) Maier 1979; Stähli 1985; Fauth 1995: 10 f.

21) $C f$. Merkelbach 1992: 69-76.

22) Daniel and Maltomini 1990: 147 1. 27.

23) Bonner 1950: 188.

24) Cf. Daniel and Maltomini 1992: 330 (Index).

25) Michel 2001: 133, nº 216

26) Nilsson 1951: 61: "The rivalry with the magic papyri is evident, but while these were the property of specialists, magical technicians, the amulets teach us what was current among the people. ... I refer to the commonest types of magical amulets, the god with a cock's head, with snakes instead of legs, and clad in Roman military costume". For the Asia Minor originated magical amulets with this common representation of Abrasax, see Konuk and Arslan 2000: 190, n 166; Arslan et al. 2011: 175; Altınoluk 2013: 13-18. Abrasax is also shown in an anguiped form on two seal impressions discovered from Zeugma excavations. See Önal $2007: \mathrm{n}^{\circ} 155-156$. 


\section{BIBLIOGRAPHY}

Altınoluk, S., 2013: "Batı Anadolu'dan İki Tılsımlı Obje: Abrasaks", in Tekin, O., Sayar, M.H. and Konyar, E. (eds.), Tarhan Armağanı. Essays in Honour of $M$. Taner Tarhan, Istanbul: 13-18.

Arslan, M., Metin, M., Cinemre, M.O., Çelik, T. and Türkmen, M., 2011: "Juliopolis Nekropolü 2010 Yılı Kazı Çalışmaları”, 20. Müze Çalışmaları ve Kurtarma Kazllarl Sempozyumu (25-29 Nisan 2011), Bodrum, Kültür Varlıkları ve Müzeler Genel Müdürlüğü Yayınları 152: $169-188$.

Barb, A.A., 1957: "Abraxasstudien”, in Hommages à W. Deonna (Collection Latomus 28), Brussels: 67-86.

Bonner, C., 1950: Studies in Magical Amulets, Ann Arbor.

Daniel, R.W. and Maltomini, F., 1990: Supplementum Magicum I (Suppl. Mag. I), Opladen.

- 1992: Supplementum Magicum II (Suppl. Mag. II), Opladen.

Dölger, F.J., 1920: Sol Salutis Gebet und Gesang im christlichen Altertum: mit besonderer Rücksicht auf die Ostung in Gebet und Liturgie, Münster.

Fauth, W., 1995: Helios Megistos. Zur synkretistischen Theologie der Spätantike, Leiden.

González, M.M. and Prieto, M.L., 1993: "Ein Abrasax-Ring aus La Obneda (Spanien)", ZPE 97: 130.

Güntert, H., 1930/1: Handwörterbuch des deutschen Aberglaubens 3, Berlin/New York, s.v. Hahn: 1325-1336.

Harrauer, H., 1992: "इOYBPOM, Abrasax, Jahwe u. a. aus Syrien. Mit einer Einleitung von Jawdat Chehade", Tyche 7: 39-44.

Konuk, K. and Arslan, M., 2000: Anadolu Antik Yüzük Taşlarl ve Yüzükleri / Ancient Gems And Finger Rings From Asia Minor, Yüksel Erimtan Koleksiyonu / The Yüksel Erimtan Collection, Ankara.

Lacroix, L., 1965: Monnaies et colonisation dans l'occident grec, Brussels.
Le Glay, M., 1981: s.v. Abraxas, LIMC I: 2-7.

Maier, J., 1979: "Die Sonne im religiösen Denken des antiken Judentums", in ANRW II 19, 1, Berlin/New York: 346-412.

Merkelbach, R. and Totti, M., 1990: Abrasax. Ausgewählte Papyri religiösen und magischen Inhalts 1, Opladen.

- 1991: Abrasax 2. Ausgewählte Papyri religiösen und magischen Inhalts, Opladen.

Merkelbach, R., 1992: Abrasax 3. Ausgewählte Papyri religiösen und magischen Inhalts, Opladen.

- 1996: Abrasax 4. Ausgewählte Papyri religiösen und magischen Inhalts, Opladen.

Michel, S., 2001: Die magischen Gemmen im Britischen Museum, London.

- 2004: Die Magischen Gemmen: Zu Bildern und Zauberformeln auf geschnittenen Steinen der Antike und Neuzeit, Berlin.

Nilsson, M.P., 1951: "The Anguipede of the Magical Amulets", The Harvard Theological Review 44: 61-64.

Nollé, J., 2007: Kleinasiatische Losorakel. Astragalund Alphabetchresmologien der hochkaiserzeitlichen Orakelrenaissance, München.

Orth, A., 1913: s.v. Huhn, RE VIII: 2519-2536.

Önal, M., 2007: Clay Seal Impressions of Zeugma / Zeugma Mühür Basklarl, Ankara.

Philonenko, M., 1979: "L'anguipède alectorocéphale et le dieu Iaô", CRAI 123: 297-304.

Sholem, G.G., 1965: Jewish Gnosticism, Merkabah Mysticism, and Talmudic Tradition, based on the Israel Goldstein Lectures delivered at the Jewish Theological Seminary of America, New York.

Stähli, H.P., 1985: Solare Elemente im Jahweglauben des Alten Testaments, Freiburg (Schweiz)/Göttingen.

Zazoff, P., 1965: "Gemmen in Kassel", $A A$ 80: 1115 



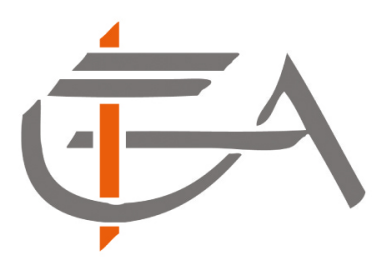

Institut Français

d'Etudes Anatoliennes

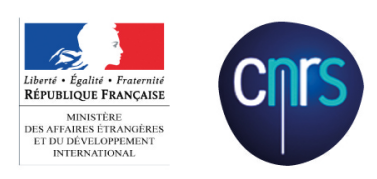

Peinture rupestre préhistorique, Sağlık Köy, près d'Alabanda, Turquie (cliché Suat Ateşlier). 